OPEN ACCESS

Edited by:

Constantinos Petrovas, Centre Hospitalier Universitaire Vaudois (CHUV), Switzerland

Reviewed by: Matthew H. Collins, Emory University, United States

Rebecca M. Lynch, George Washington University, United States

*Correspondence: Shelly J. Krebs skrebs@hivresearch.org

Specialty section: This article was submitted to Viral Immunology, a section of the journal

Frontiers in Immunology

Received: 24 October 2020 Accepted: 14 December 2020 Published: 04 February 2021

Citation:

Dussupt V, Modjarrad K and Krebs SJ (2021) Landscape of Monoclonal Antibodies Targeting Zika and Dengue: Therapeutic Solutions and Critical Insights for Vaccine Development.

Front. Immunol. 11:621043. doi: 10.3389/fimmu.2020.621043

\section{Landscape of Monoclonal Antibodies Targeting Zika and Dengue: Therapeutic Solutions and Critical Insights for Vaccine Development}

\author{
Vincent Dussupt ${ }^{1,2,3}$, Kayvon Modjarrad $^{1}$ and Shelly J. Krebs ${ }^{1,2,3 *}$ \\ ${ }^{1}$ Emerging Infectious Diseases Branch, Walter Reed Army Institute of Research, Silver Spring, MD, United States, \\ 2 U.S. Military HIV Research Program, Walter Reed Army Institute of Research, Silver Spring, MD, United States, \\ ${ }^{3}$ Henry M. Jackson Foundation for the Advancement of Military Medicine, Bethesda, MD, United States
}

The unprecedented 2015-2016 Zika outbreak in the Americas sparked global concern and drove the rapid deployment of vaccine and therapeutic countermeasures against this re-emerging pathogen. Alongside vaccine development, a number of potent neutralizing antibodies against Zika and related flaviviruses have been identified in recent years. Highthroughput antibody isolation approaches have contributed to a better understanding of the B cell responses elicited following infection and/or vaccination. Structure-based approaches have illuminated species-specific and cross-protective epitopes of therapeutic value. This review will highlight previously described monoclonal antibodies with the best therapeutic potential against ZIKV and related flaviviruses, and discuss their implications for the rational design of better vaccine strategies.

Keywords: Zika virus, Dengue virus, neutralizing antibody, monoclonal antibody, vaccine, therapeutics

\section{INTRODUCTION}

The first generation of flavivirus vaccines, such as the yellow fever virus (YFV) 17D vaccine, were developed empirically by serially passaging pathogenic virus in animal tissues until attenuated virus variants emerged that were suitable to be used as a safe, live and effective vaccine $(1,2)$. Others, like the licensed Japanese encephalitis virus (JEV) and tick-borne encephalitis virus vaccines are made from whole inactivated viral particles $(3,4)$, a strategy that has been recapitulated for experimental vaccines for other flaviviruses, such as dengue virus (DENV) and Zika virus (ZIKV) (5-7). In recent decades, the advent of a novel suite of technologies has enabled a more rational and targeted approach to the rapid discovery and development of immunogens for emerging pathogens $(8,9)$. In particular, whole genome sequencing has revolutionized vaccinology, translating genomic information to vaccine candidates, through a process termed "reverse vaccinology". The next phase of this once fresh approach-known as "reverse vaccinology 2.0 "-now assembles a more multi-faceted, seamless pipeline of complementary disciplines that 1) pre-screens human donors 2) identifies and sequences B cell receptors of highly specific or broadly reactive B cells 3) expresses these sequences as monoclonal antibodies (mAbs) and 4) structurally and functionally characterizes the targeted antibody epitopes. However, this pathway not only applies to the development of vaccines immunogens, but is now the basis to rapidly scale prophylactic and therapeutic 
monoclonal antibodies as well $(10,11)$. These new technologies were first pioneered through research of viral pathogens, such as HIV and influenza, for which effective vaccines traditionally have been difficult to develop (11-13). The biology and methodologies elucidated by working on these other viruses have paid dividends for the development of countermeasures to other infectious diseases, particularly flaviviruses, which threaten the health of people throughout the world. Over the last several years, a large number of monoclonal antibodies protective against flaviviruses have been reported, providing new insights into neutralizing epitopes, new avenues for vaccine design, and potential combinations of mAbs that may be used for cross-flavivirus prophylaxis or treatment. In this article, we will review the current status of neutralizing monoclonal antibodies against ZIKV and DENV and provide perspectives on protective epitopes that may be of therapeutic value or guide the development of successful flavivirus vaccines.

\section{THE COMPLEX ZIKA VIRUS/DENGUE VIRUS SEROLOGIC LANDSCAPE}

Neutralizing antibody responses are the major correlate of protection from flavivirus infection (14-16). The primary target of these protective antibodies is the viral envelope (E) protein, incorporated into the budding virion as a premembrane (prM)-E precursor that is cleaved into membrane (M) and $\mathrm{E}$ proteins upon maturation. In mature particles, $\mathrm{E}$ is the only accessible protein at the virion surface, while $M$ anchors $E$ at the viral membrane. E consists of 3 domains DI, DII and DIII. The former, located at the center of the E protomer, links the putative host cell receptor binding domain, DIII, with DII, which drives dimerization and harbors the fusion loop at its distal end (Figure 1) (49). Most neutralizing antibodies act either by blocking virion binding to its host receptor or by interfering with the structural rearrangements necessary for $\mathrm{E}$ fusogenic activity, upon entry to the endocytic pathway (50). Mature ZIKV and DENV virions display 180 copies of E protein, arranged as anti-parallel dimers that cover the entire virion surface. These E dimers are further organized in an "herringbone" pattern with icosahedral architecture $(51,52)$. However, each of the three E proteins within an asymmetrical unit yields non-equivalent interactions. As a result, a given antibody epitope on the $\mathrm{E}$ monomer is presented in three different conformations on the mature particle. Quaternary epitopes, spanning several E protomers, are of great interest as they are often the target of potent neutralizing antibodies $(22,53)$. On the other hand, cryptic epitopes, transiently exposed due to the highly dynamic structure of $\mathrm{E}$, have been associated with strain-specific poorly neutralizing responses (49).

Whereas E proteins across all flaviviruses share sequence and structural similarities, phylogenetic analyses have revealed that ZIKV is most related to the $4 \mathrm{DENV}$ serotypes (25). Accordingly, both DENV convalescent plasma and DENV-directed monoclonal antibodies show substantial cross-reactivity to ZIKV $(54,55)$. These findings have prompted some investigators to consider ZIKV as the $5^{\text {th }}$ member of the DENV serocomplex (54). Investigations into the epidemiologic overlap of DENV and ZIKV, in areas where the two viruses co-circulate, have revealed important findings about their immunologic cross-reactivity. For example, pre-existing DENV immunity in humans was associated with reduced ZIKV symptoms in a pediatric cohort in Nicaragua (56), as well as reduced symptoms and a lower risk of ZIKV infection in a large prospective Brazilian cohort (57). Additionally, mothers who were infected with ZIKV, but had serologic evidence of pre-existing DENV, showed no increased risk of microcephaly in their fetuses (58). There are sufficient data to suggest serologic crosstalk between ZIKV and the four DENV serotypes that requires consideration when designing vaccines and antibodybased therapies.

\section{NEUTRALIZING ANTIBODIES AGAINST ZIKA AND DENGUE}

In an effort to develop categorical solutions to virus genuses or families, passive immunotherapy is gaining traction as a plausible alternative to vaccines and anti-virals. This has been made possible by the identification of highly potent and/or broadly cross-reactive antibodies (9), through large-scale single $\mathrm{B}$ cell isolation and screening approaches. These exceptionally potent antibodies have $50 \%$ inhibitory concentration (IC50) in the low $\mathrm{ng} / \mathrm{ml}$ range, affording protection at concentrations readily achievable in vivo. The vast majority of these antibodies neutralize flaviviruses by locking $\mathrm{E}$ dimers in the pre-fusion conformation and preventing structural rearrangements necessary for E fusogenic activity. Engineering of these neutralizing antibodies can further enhance their potency and breadth as well as improve their pharmacokinetic properties (59, 60 ), so that a single infusion could confer protection over several weeks. Other modifications such as fine-tuning or abrogation of their effector functions are valuable tools $(61,62)$. However, given concerns of antibody-dependent enhancement (ADE) of infection between ZIKV and DENV (41, 54, 63, 64), ZIKV therapeutic mAbs would likely be best deployed harboring Fcsilenced mutations (LALA or YTE/FQQ) (65-68), to eliminate any risks of potentiating DENV infections, especially when Fc effector functions appear dispensable for protection in small animal models $(26,33,41,45)$.

\section{The E Dimer Epitope}

A well-described protective epitope of flaviviruses is the E dimer epitope (EDE), a conserved quaternary epitope that is the target of potent cross-neutralizing antibodies. Originally discovered in DENV-infected patients (27), EDE mAbs were subsequently found to cross-neutralize ZIKV, and with high potency like EDE1-C8 (25) (Figure 1). The EDE is a particularly vulnerable site that is highly conserved across flaviviruses, as it overlaps with the binding site of prM in the immature particle. prM plays a key role during viral egress in the acidic Golgi compartment of the producer cell by preventing premature exposure of the fusion loop. 


\begin{tabular}{|c|c|c|c|c|c|c|c|c|c|}
\hline & Virus & $\begin{array}{l}\text { Prototypical } \\
\text { antibody }\end{array}$ & $\begin{array}{c}\text { Similar } \\
\text { antibodies }\end{array}$ & Species & Source, isolation strategy & $\begin{array}{l}\text { Epitope,critical } \\
\text { residues }\end{array}$ & Neutralizationpotency & $\begin{array}{c}\text { Cross } \\
\text { neutralization }\end{array}$ & References \\
\hline \multirow{2}{*}{$\begin{array}{l}\frac{0}{8} \\
\frac{0}{c} \\
\frac{0}{0} \\
\frac{0}{4}\end{array}$} & ZIKV-DENV & 2A10G6 & $4 \mathrm{G} 2$ & mouse & $\begin{array}{l}\text { DENV-2 immunized mouse, } \\
\text { hybridoma screening }\end{array}$ & $\begin{array}{l}\text { Fusion loop } \\
\text { W101 }\end{array}$ & * & $\begin{array}{l}\text { ZIKV, DENV1-4, } \\
\text { WNV }\end{array}$ & $(17-19)$ \\
\hline & ZIKV-DENV & MZ54 & MZ56 & human & $\begin{array}{l}\text { Flavivirus-experienced ZIKV } \\
\text { vaccinee, B cell sort using whole } \\
\text { virus + ZIKV/DENV E probes }\end{array}$ & $\begin{array}{l}\text { Fusion loop } \\
\text { W101 }\end{array}$ & $\star \star$ & $\begin{array}{l}\text { ZIKV, DENV1-4, } \\
\text { WNV }\end{array}$ & (20) \\
\hline \multirow{2}{*}{$\begin{array}{l}\overline{\overline{0}} \\
\overline{\overline{0}}\end{array}$} & $\mathrm{ZIKV}$ & Z3L1 & & human & $\begin{array}{l}\text { ZIKV-infected human, memory B } \\
\text { cell sort using ZIKV E probe }\end{array}$ & DI, DI-DII hinge & ** & ZIKV specific & (21) \\
\hline & DENV-1 & $1 F 4$ & & human & $\begin{array}{l}\text { B cells from DENV immune human, } \\
\text { screening of EBV-transformed B } \\
\text { cells from total PBMCs }\end{array}$ & DI, DI-DII hinge & 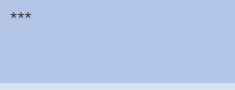 & DENV-1 specific & $(22,23)$ \\
\hline$\overline{\bar{D}}$ & ZIKV-DENV & MZ20 & $1 C 19$ & human & $\begin{array}{l}\text { Flavivirus-experienced ZIKV } \\
\text { vaccinee, B cell sort using whole } \\
\text { virus + ZIKV/DENV E probes }\end{array}$ & $\begin{array}{l}\text { DIl bc loop } \\
\text { R73 }\end{array}$ & $\star \star *$ & $\begin{array}{l}\text { ZIKV, DENV1-4, } \\
\text { JEV }\end{array}$ & $(20,24)$ \\
\hline \multirow{2}{*}{ 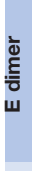 } & ZIKV/DENV & EDE1-C8 & $\begin{array}{l}\text { EDE1-B10, } \\
\text { C10, EDE2- } \\
\text { A11 }\end{array}$ & human & $\begin{array}{l}\text { Patients with acute DENV infection, } \\
\text { screening of total plasmablasts }\end{array}$ & $\begin{array}{l}\text { E dimer } \\
\text { M68, S70, S72, } \\
\text { G104, Q253, T315 }\end{array}$ & $\begin{array}{l}{ }^{\star \star \star}(\mathrm{C} 8) \\
{ }^{\star \star \star \star}(\mathrm{B} 10)\end{array}$ & ZIKV, DENV1-4 & $(25-30)$ \\
\hline & DENV-2 & 2D22 & & human & $\begin{array}{l}\text { B cells from DENV immune human, } \\
\text { screening of EBV-transformed B } \\
\text { cells from total PBMCs }\end{array}$ & E dimer & ${ }^{\star \star}(\mathrm{DENV}-2)$ & DENV-2 specific & $(22,31)$ \\
\hline \multirow{5}{*}{ 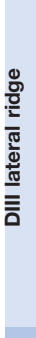 } & ZIKV & ZV-67 & ZV-54 & mouse & $\begin{array}{l}\text { ZIKV-infected mouse with EDIII } \\
\text { boost, hybridoma screening }\end{array}$ & $\begin{array}{l}\text { DIII lateral ridge } \\
\text { K394 }\end{array}$ & $\star *$ & ZIKV specific & (32) \\
\hline & $\begin{array}{l}\text { ZIKV/ } \\
\text { DENV-1 }\end{array}$ & Zo04 & $\begin{array}{l}\text { Z006, 1C11, } \\
\text { ZIKV-116, } \\
\text { SMZAb5 }\end{array}$ & human & $\begin{array}{l}\text { B cell from a ZIKV-infected human, } \\
\text { memory B cell sort using ZIKV EDIII } \\
\text { probe }\end{array}$ & $\begin{array}{l}\text { DIII lateral ridge } \\
\text { E393, K394 }\end{array}$ & 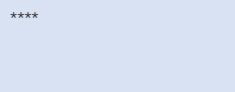 & ZIKV, DENV-1 & $(33-37)$ \\
\hline & DENV-1 & E105 & E106 & mouse & $\begin{array}{l}\text { DENV-1 infected mouse with EDIII } \\
\text { boost, hybridoma screening }\end{array}$ & DIII lateral ridge & 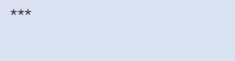 & DENV-1 specific & (38) \\
\hline & DENV-2 & 3H5 & $2 \mathrm{C} 8$ & mouse & $\begin{array}{l}\text { DENV-2 infected mouse, hybridoma } \\
\text { screening }\end{array}$ & DIII lateral ridge & 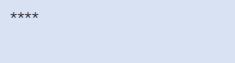 & DENV-2 specific & $(39,40)$ \\
\hline & $\mathrm{ZIKV}$ & ZKA190 & & human & $\begin{array}{l}\text { B cell from a ZIKV-infected human, } \\
\text { EBV-transformed B cell from total } \\
\text { memory B cells }\end{array}$ & $\begin{array}{l}\text { DI-DIII linker, DIII } \\
\text { lateral ridge }\end{array}$ & 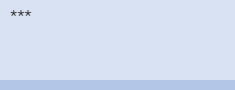 & ZIKV specific & $(41,42)$ \\
\hline \multirow{2}{*}{ 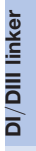 } & ZIKV/DENV & MZ4 & $\begin{array}{l}\text { MZ1, MZ2, } \\
M Z 24\end{array}$ & human & $\begin{array}{l}\text { Flavivirus-experienced ZIKV } \\
\text { vaccinee, B cell sort using whole } \\
\text { virus + ZIKV/DENV E probes }\end{array}$ & $\begin{array}{l}\text { DI-DIII linker } \\
\text { Y305 }\end{array}$ & 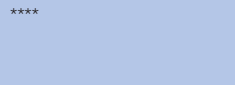 & ZIKV, DENV1-4 & (20) \\
\hline & DENV-4 & $5 \mathrm{H} 2$ & & chimpanzee & $\begin{array}{l}\text { Phage display from repertoire of } \\
\text { infected chimpanzee }\end{array}$ & DI, DI-DIII linker & ${ }^{\star \star}(\mathrm{DENV}-4)$ & DENV-4 specific & $(43,44)$ \\
\hline \multirow{2}{*}{ 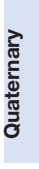 } & ZIKV & ZIKV-117 & & human & $\begin{array}{l}\text { B cell from a ZIKV-infected human, } \\
\text { screening of EBV-transformed B } \\
\text { cells from total PBMCs }\end{array}$ & $\begin{array}{l}\text { dimer-dimer } \\
\text { interface } \\
\text { D67, Q89, K118 }\end{array}$ & $\star \star \star \star ~$ & ZIKV specific & $(45,46)$ \\
\hline & DENV-3 & $5 \mathrm{~J} 7$ & & human & $\begin{array}{l}\text { B cells from DENV immune human, } \\
\text { screening of EBV-transformed B } \\
\text { cells from total PBMCs }\end{array}$ & $\begin{array}{l}\text { Quaternary DI-DII } \\
\text { hinge, DII, DIII on } 3 \\
\text { different protomers }\end{array}$ & 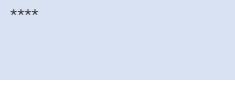 & DENV-3 specific & $(22,47)$ \\
\hline
\end{tabular}

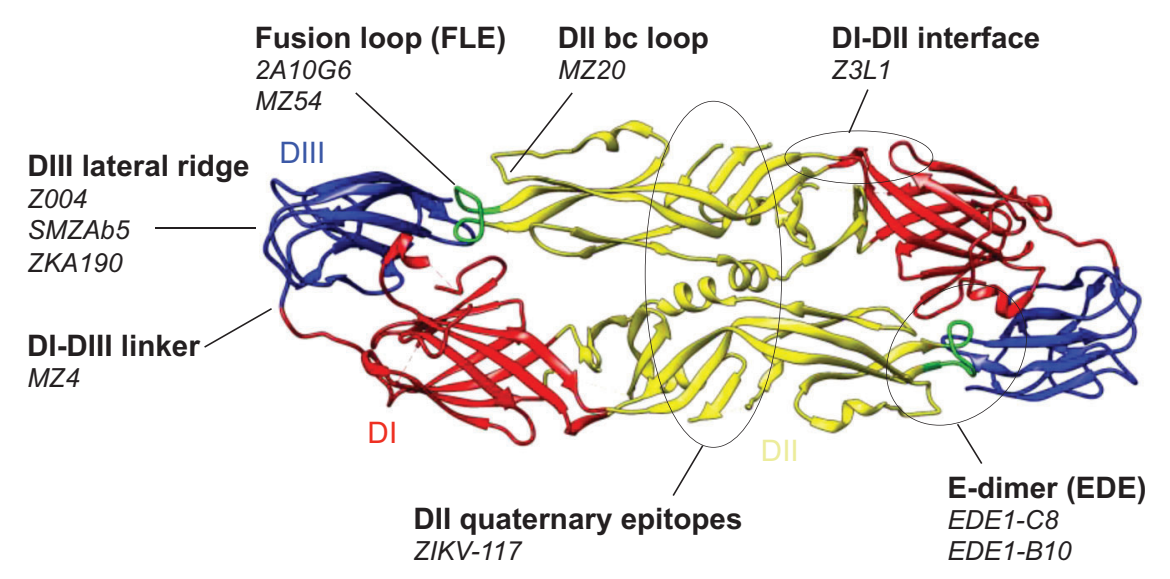

FIGURE 1 | Neutralizing epitopes of Zika virus (ZIKV) and dengue virus (DENV) monoclonal antibodies. Top, Characteristics of prototypical ZIKV and DENV neutralizing antibodies grouped by epitope specificities. Neutralization potency is based on IC50 against ZIKV unless otherwise indicated. IC50 (ng/ml) are indicated as follows: ${ }^{\star \star \star \star}(<10 \mathrm{ng} / \mathrm{ml}) ;{ }^{\star \star \star}(10-50 \mathrm{ng} / \mathrm{ml}) ;{ }^{* \star}(50-500 \mathrm{ng} / \mathrm{ml}) ;{ }^{*}(>500 \mathrm{ng} / \mathrm{ml})$. Bottom, the same neutralizing epitopes mapped onto the ZIKV E dimer. The ZIKV E dimer, PDB 5LBV (25), is shown in ribbon representation with the respective domains of each protomer colored in red (DI), yellow (DII), and blue (DIII) while the fusion loop in DIl is highlighted in green. This visual was generated using UCSF Chimera (48). 
$\mathrm{B} 10$, another EDE mAb, was found to be particularly potent against ZIKV and protected mice against lethality and fetal demise (26). It provided robust therapeutic as well as prophylactic efficacy against ZIKV infection in rhesus monkeys and, importantly, did not induce viral escape, which is rare in antibody monotherapy (28).

The discovery of these potent EDE mAbs encouraged the development of immunogens capable of inducing B cell responses of similar specificities through vaccination. The addition of disulfide bonds necessary to stabilize the dimeric $\mathrm{E}$ also has the secondary benefit of masking the fusion loop epitope (69), another conserved epitope that has yielded cross-reactive but poorly neutralizing antibody responses (49). Stabilized dimers also present virus-specific, protective E dimer epitopes, recognized by mAbs such as 2D22 (70), a DENV-2 specific antibody. Efforts to develop EDE immunogens are ongoing and hold promise in eliciting broad and potent flavivirus protective responses (71).

\section{Domain III-Directed Antibodies}

Antibodies to DIII have been shown to develop at later stages of ZIKV infection, and are associated with increased neutralization potency (72). While DIII antibodies have been readily elicited in murine models $(32,73)$ and are believed to be less frequent in humans (74), several potent DIII antibodies have been isolated from ZIKV-infected patients (33-37) (Figure 1). Prototypical DIII neutralizing antibodies target the lateral ridge epitope; these include mouse mAbs 3H5 (DENV-2) (40), E16 (WNV) (75), ZV-67 (ZIKV) (67) and human mAbs Z004 (34), SMZAb5 (33) and ZKA190 (42). Unlike the EDE directed B10 mAb, passive immunotherapy with single DIII antibodies quickly select for resistant virus variants. Therefore, a combination of at least two DIII antibodies (37) or the use of bi-specific antibodies targeting different domains (42) may prevent viral escape and are likely to be more effective for therapeutic use.

\section{DI/DIII Linker}

A new class of potent ZIKV/DENV-2 cross-neutralizing antibodies targeting the DI/DIII linker region was recently identified in a donor with pre-existing DENV immunity following vaccination with a whole ZIKV inactivated virus. One prototypic $\mathrm{mAb}, \mathrm{MZ4}$, is highly potent against ZIKV and DENV-2 (20) (Figure 1). Since the DI/DIII linker is highly conserved across flavivirus species, secondary contacts with DI and DIII likely define the breadth and potency of such antibodies. Other mAbs such as ZKA190 (42) and 5H2 (43) also engages the DI/DIII linker, but more extensive interaction with DIII, or DI, restricts their specificity to ZIKV and DENV-4, respectively. The highly conserved hinge region between DI and DIII appears to be another site of vulnerability on the flavivirus E protein. This flexible inter-domain linker allows for major structural rearrangements during formation of the fusogenic trimer (76), which makes it an attractive target for the development of new immunogens.

\section{Quaternary Epitopes}

Another group of potent neutralizing antibodies target more complex virion-specific quaternary epitopes consisting of multiple E protomers and are, as such, more likely to be virus specific due to differences in sequence, glycosylation and structural plasticity of $\mathrm{E}$ across flaviviruses (Figure 1). One example of such antibody is ZIKV-117, a ZIKV-specific DII antibody that cross-links monomers within the E dimers as well as between neighboring dimers, preventing the reorganization of E necessary for viral entry (46). Whereas the antigen binding fragments (Fab) of antibodies binding EDE (31) and DIII (42) engage all $180 \mathrm{E}$ copies on the virion in a $1: 1$ stoichiometry, ZIKV-117 needs only 60 Fabs to effectively cross-link the glycoprotein shell, contributing to its potent neutralization capacity and its ability to prevent fetal infection and intrauterine fetal demise in mice (45). Similarly, the DENV-3 specific antibody $5 \mathrm{~J} 7$ is exceptionally potent and able to coat the virus surface with only 60 Fab molecules, with a single Fab binding across the DI-DII hinge, DII and DIII on three different E protomers (47). 5J7 interferes with both attachment and fusion steps, consistent with its multi-domain targeting ability.

\section{GENETICS OF ZIKA AND DENGUE NEUTRALIZING ANTIBODIES}

Understanding of the antibody repertoire generated by flavivirus infections has been largely shaped by studies aimed at identifying potent therapeutic antibodies in a few select donors and may not generalize to the most prevalent responses. Higher throughput and more systematic antibody characterization (77) is needed to obtain unbiased insights into the $\mathrm{B}$ cell responses elicited by flavivirus infection and vaccination. Nonetheless, the most comprehensive study to date has revealed a wide array of $\mathrm{VH}$ gene usage with limited overlap between individuals and no association between $\mathrm{VH}$ gene and epitope specificity (41). Epitopes such as the fusion loop and the E dimer are targeted by highly divergent antibodies which may make specificity predictions based on gene usage only difficult (27) (Table 1). One notable exception is the case of the DIII lateral ridgetargeting antibodies. Recurrent lineages using the VH3-23/ VK1-5 combination have been identified in at least eight donors from central and south Americas by four independent groups (33-36). This type of antibodies was further associated with cross-neutralization of DENV-1, suggesting a role of prior DENV-1 immunity in priming those responses. However, one donor did not display serologic evidence of DENV-1 infection (35), indicating that primary ZIKV infection can, in principle, also elicit such lineage. While other specificities have not been studied as extensively, it is likely that other flavivirus-specific public lineages will emerge. A common observation between all these studies is the very low level of somatic hypermutation observed, even among potent neutralizing antibodies $(34,41,78)$. A germline-like ZIKV specific neutralizing antibody with no apparent diversification through affinity maturation was 
TABLE 1 | Genetics and characteristics of Zika virus (ZIKV) and dengue virus (DENV) neutralizing monoclonal antibodies.

\begin{tabular}{|c|c|c|c|c|c|c|c|c|c|}
\hline Antibody & $\begin{array}{l}\text { Heavy } \\
\text { chain }\end{array}$ & $\begin{array}{l}\text { VH\% } \\
\text { SHM }\end{array}$ & $\begin{array}{l}\text { Light } \\
\text { chain }\end{array}$ & $\begin{array}{l}\text { HCDR3 } \\
\text { length }\end{array}$ & VDJ junction & Epitope & $\begin{array}{c}\text { Neutralization } \\
\text { potency }\end{array}$ & $\begin{array}{c}\text { Cross } \\
\text { neutralization }\end{array}$ & References \\
\hline $\begin{array}{l}\text { ZIKV-117 } \\
5 J 7\end{array}$ & $\begin{array}{l}\text { VH3-30 } \\
\text { VH1-69 }\end{array}$ & & $\begin{array}{l}\text { VK3-15 } \\
\text { VK1-39 }\end{array}$ & $\begin{array}{l}12 \\
14\end{array}$ & CARDKELLFSRAFDIW & $\begin{array}{l}\text { Quaternary } \\
\text { Quaternary }\end{array}$ & $\begin{array}{l}\star \star \star \star \\
\star \star \star \star\end{array}$ & $\begin{array}{l}\text { ZIKV specific } \\
\text { DENV-3 specific }\end{array}$ & $\begin{array}{c}(45) \\
(22,47)\end{array}$ \\
\hline MZ4 & VH4-59 & 5.5 & VL1-44 & 14 & CAGLDRYSWNEGGDHW & $\begin{array}{l}\text { DI-DIII } \\
\text { linker }\end{array}$ & $\star \star \star \star$ & ZIKV, DENV2-3 & (20) \\
\hline Z004 & VH3-23 & & VK1-5 & 15 & CAKDRGPRGVGELFDSW & $\begin{array}{l}\text { DIII lateral } \\
\text { ridge }\end{array}$ & 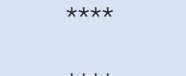 & ZIKV, DENV-1 & (34) \\
\hline$\underline{Z 006}$ & VH3-23 & & VK1-5 & 13 & CVRDRSNGWSSINLW & $\begin{array}{l}\text { DIII lateral } \\
\text { ridge }\end{array}$ & 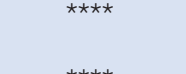 & ZIKV, DENV-1 & (34) \\
\hline$\underline{\mathrm{SMZAB5}}$ & VH3-23 & & VK1-5 & 15 & CAKDRSTRGFGELLNYW & $\begin{array}{l}\text { DIII lateral } \\
\text { ridge }\end{array}$ & $\star \star \star \star$ & ZIKV, DENV-1 & (33) \\
\hline ZIKV-116 & VH3-23 & 6.5 & VK1-5 & 15 & CAKDRLSRGVGELYDSW & $\begin{array}{l}\text { DIII lateral } \\
\text { ridge }\end{array}$ & $\star \star \star$ & ZIKV, DENV-1 & $(36,45)$ \\
\hline$\underline{1 C 11}$ & VH3-23 & 3.5 & VK1-5 & 14 & CAKDRIVLGLELFDSW & $\begin{array}{l}\text { DIII lateral } \\
\text { ridge }\end{array}$ & $\star \star$ & ZIKV, DENV-1 & (35) \\
\hline ZKA190 & VH3-30 & 2.7 & VK3-20 & 23 & CAKSGTQYYDTTGYEYRGLEYFGYW & $\begin{array}{l}\text { DIII lateral } \\
\text { ridge }\end{array}$ & $\star \star \star$ & ZIKV specific & $(42)$ \\
\hline EDE1-C8 & VH3-64D & 6.9 & VK3-11 & 15 & CVGGYSNFYYYYTMDVW & E dimer & 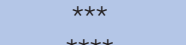 & ZIKV, DENV1-4 & $(25,27)$ \\
\hline EDE1-C10 & $\mathrm{VH} 1-3$ & 2.8 & VL2-14 & 21 & CARDKVDDYGDYWFPTLWYFDYW & E dimer & $\star \star \star \star ~$ & ZIKV, DENV1-4 & $(25,27)$ \\
\hline EDE2-A11 & VH3-74 & 8.7 & VL2-23 & 26 & CVRDGVRFYYDSTGYYPDSFFKYGMDVW & E dimer & $\star \star$ & ZIKV, DENV1-4 & $(25,27)$ \\
\hline 2D22 & VH1-69 & & VL1-47 & 9 & CARRPQSIFDW & E dimer & ${ }^{\star \star}(\mathrm{DENV}-2)$ & DENV-2 specific & $(22)$ \\
\hline MZ20 & VH3-11 & 10.4 & VK1-33 & 10 & CVRAGGARIENW & DIl bc loop & ${ }^{\star \star}(\mathrm{ZIKV})$ & $\begin{array}{l}\text { ZIKV, DENV1-4, } \\
\text { JEV }\end{array}$ & (20) \\
\hline MZ54 & VH3-11 & 10.4 & VK1-33 & 10 & CVCAGGGRTDYW & Fusion loop & $\star \star$ & $\begin{array}{l}\text { ZIKV, DENV1-4, } \\
\text { WNV }\end{array}$ & (20) \\
\hline MZ56 & VH3-64 & 4.9 & VL2-11 & 17 & CARGWYYYDSRAYWYFDLW & Fusion loop & $\star \star$ & $\begin{array}{l}\text { ZIKV, DENV1-4, } \\
\text { WNV }\end{array}$ & (20) \\
\hline Z3L1 & VH3-30 & & VL1-51 & 10 & CARDHLGWSSIW & $\begin{array}{l}\text { DI, DI-DII } \\
\text { hinge }\end{array}$ & $\star \star$ & ZIKV specific & $(21)$ \\
\hline $1 F 4$ & VH3-33 & & VL1-36 & 18 & CARDKNPGTKPYYHYGMDVW & $\begin{array}{l}\text { DI, DI-DII } \\
\text { hinge }\end{array}$ & $\star \star \star$ & DENV-1 specific & $(22,23)$ \\
\hline
\end{tabular}

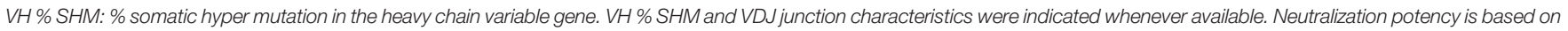

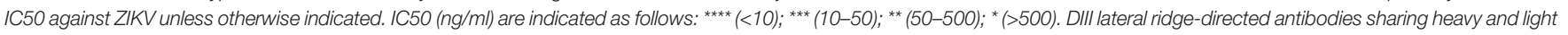
chain $V$ gene usage are underlined.

identified, indicating that ZIKV can be readily targeted by germline BCRs (79).

\section{IMPLICATIONS FOR VACCINE DESIGN AND CONCLUSIONS}

Several neutralizing epitopes on ZIKV and DENV 1-4 have been identified as desirable targets for successful immunogens $(17,20-$ $22,25,32-36,45)$. In our opinion, the ideal vaccine will be able to elicit protective cross-neutralizing antibodies to ZIKV and DENV 1-4, providing cross-protection while minimizing responses to non-neutralizing epitopes that may result in ADE. Although there are antigenic differences between ZIKV and DENV, and within DENV 1-4, there is evidence that a panZIKV/DENV flavivirus vaccine could be achieved by using different approaches that target the antigenic similarities between these viruses. For example, stabilized E-dimers may be promising candidates as they display EDE, DII, DI-DIII, and DIII neutralization epitopes, which may be exploited by sequential vaccine strategies with different serotypes to guide B cell responses toward conserved ZIKV/DENV cross-neutralizing epitopes (69-71). Further examination is needed on whether they should be used as subunit vaccines or multivalently displayed on scaffold/nanoparticles. Vaccines based on whole virus or virus-like particles are antigenically unique in their ability to present quaternary epitopes capable of eliciting some of the most potent neutralizing antibodies (20,45), pending various inactivation methods $(5,80)$. A potential issue with whole inactivated flavivirus vaccines is the residual presence of prM, a target for non-neutralizing antibodies, which would need to be considered in future strategies. However, the development of novel stable cell lines overexpressing furin would allow for the production of fully mature virions, devoid of prM (81), if viral sequences produced within these cell lines are representative of circulating viruses. Recent advances in virus inactivation techniques could further enhance the immunogenicity of such vaccines and allow for fewer immunizations with higher neutralizing antibody titers (82). Finally, among several alternative vaccine platforms, viral-vectored vaccines based on non-replicating adenoviruses that encode for the ZIKV M and E proteins are quickly moving forward. Recent studies revealed 
that human Ad26, simian RhAd52, ChAd7, and GAd have all been shown to elicit protective responses in animal studies, with rapid and durable neutralizing antibody responses (8388). It has yet to be determined the neutralizing targets of these protective responses.

Clearly the isolation of highly potent neutralizing antibodies coupled with detailed examination of their properties at the molecular level have provided pivotal insights into the protective targets that can, in turn, inform immunogen design or ultimately a cross-flavivirus vaccine. Until these developments come to fruition, these mAbs offer new options in treatment modalities for flavivirus infections, or as prophylaxis during times of an outbreak to protect populations at risk such as pregnant women in the case of ZIKV or children with severe secondary DENV infections.

\section{REFERENCES}

1. Theiler M, Smith HH. The Effect of Prolonged Cultivation in Vitro Upon the Pathogenicity of Yellow Fever Virus. J Exp Med (1937) 65(6):767-86. doi: $10.1084 /$ jem.65.6.767

2. Theiler M, Smith HH. The Use of Yellow Fever Virus Modified by in Vitro Cultivation for Human Immunization. J Exp Med (1937) 65(6):787-800. doi: 10.1084 /jem.65.6.787

3. Hoke CH, Nisalak A, Sangawhipa N, Jatanasen S, Laorakapongse T, Innis BL, et al. Protection against Japanese encephalitis by inactivated vaccines. New Engl J Med (1988) 319(10):608-14. doi: 10.1056/NEJM198809083191004

4. Lehrer AT, Holbrook MR. Tick-borne Encephalitis Vaccines. J Bioterror Biodef (2011) 2011(Suppl 1):3. doi: 10.4172/2157-2526.S1-003

5. Fernandez S, Thomas SJ, De La Barrera R, Im-Erbsin R, Jarman RG, Baras B, et al. An adjuvanted, tetravalent dengue virus purified inactivated vaccine candidate induces long-lasting and protective antibody responses against dengue challenge in rhesus macaques. Am J Trop Med Hyg (2015) 92(4):698708. doi: 10.4269/ajtmh.14-0268

6. Martinez LJ, Lin L, Blaylock JM, Lyons AG, Bauer KM, De La Barrera R, et al. Safety and Immunogenicity of a Dengue Virus Serotype-1 PurifiedInactivated Vaccine: Results of a Phase 1 Clinical Trial. Am J Trop Med Hyg (2015) 93(3):454-60. doi: 10.4269/ajtmh.14-0819

7. Barouch DH, Thomas SJ, Michael NL. Prospects for a Zika Virus Vaccine. Immunity (2017) 46(2):176-82. doi: 10.1016/j.immuni.2017.02.005

8. Modjarrad K, Koff WC. Human Vaccines: Emerging Technologies in Design and Development. Amsterdam, The Netherlands: Elsevier (2017). p. 186.

9. Walker LM, Burton DR. Passive immunotherapy of viral infections: 'superantibodies' enter the fray. Nat Rev Immunol (2018) 18(5):297-308. doi: $10.1038 /$ nri.2017.148

10. Georgiou G, Ippolito GC, Beausang J, Busse CE, Wardemann H, Quake SR. The promise and challenge of high-throughput sequencing of the antibody repertoire. Nat Biotechnol (2014) 32(2):158-68. doi: 10.1038/nbt.2782

11. Rappuoli R, Bottomley MJ, D’Oro U, Finco O, De Gregorio E. Reverse vaccinology 2.0: Human immunology instructs vaccine antigen design. J Exp Med (2016) 213(4):469-81. doi: 10.1084/jem.20151960

12. Burton DR. What Are the Most Powerful Immunogen Design Vaccine Strategies? Reverse Vaccinology 2.0 Shows Great Promise. Cold Spring Harb Perspect Biol (2017) 9(11):a030262. doi: 10.1101/cshperspect.a030262

13. Crowe JEJr. Principles of Broad and Potent Antiviral Human Antibodies: Insights for Vaccine Design. Cell Host Microbe (2017) 22(2):193-206. doi: 10.1016/j.chom.2017.07.013

14. Barrett AD, Teuwen DE. Yellow fever vaccine - how does it work and why do rare cases of serious adverse events take place? Curr Opin Immunol (2009) 21 (3):308-13. doi: 10.1016/j.coi.2009.05.018

15. Van Gessel Y, Klade CS, Putnak R, Formica A, Krasaesub S, Spruth M, et al. Correlation of protection against Japanese encephalitis virus and JE vaccine

\section{AUTHOR CONTRIBUTIONS}

VD wrote the manuscript, with input and edits by KM and SK. All authors contributed to the article and approved the submitted version.

\section{FUNDING}

This work was supported by a cooperative agreement (W81XWH18-2-0040) between the Henry M. Jackson Foundation for the Advancement of Military Medicine, Inc., and the U.S. Department of Defense (DOD). The views expressed are those of the authors and should not be construed to represent the positions of the U.S. Army, the Department of Defense, or HJF.

(IXIARO((R))) induced neutralizing antibody titers. Vaccine (2011) 29 (35):5925-31. doi: 10.1016/j.vaccine.2011.06.062

16. Abbink P, Larocca RA, Visitsunthorn K, Boyd M, De la Barrera RA, Gromowski GD, et al. Durability and correlates of vaccine protection against Zika virus in rhesus monkeys. Sci Transl Med (2017) 9 (eaao4163):1-7. doi: 10.1126/scitranslmed.aao4163

17. Dai L, Song J, Lu X, Deng YQ, Musyoki AM, Cheng H, et al. Structures of the Zika Virus Envelope Protein and Its Complex with a Flavivirus Broadly Protective Antibody. Cell Host Microbe (2016) 19(5):696-704. doi: 10.1016/ j.chom.2016.04.013

18. Deng YQ, Dai JX, Ji GH, Jiang T, Wang HJ, Yang HO, et al. A broadly flavivirus cross-neutralizing monoclonal antibody that recognizes a novel epitope within the fusion loop of E protein. PloS One (2011) 6(1):e16059. doi: 10.1371/journal.pone.0016059

19. Henchal EA, Gentry MK, McCown JM, Brandt WE. Dengue virus-specific and Flavivirus group determinants identified with monoclonal antibodies by indirect immunofluorescence. Am J Trop Med Hyg (1982) 31(4):830-6. doi: 10.4269/ajtmh.1982.31.830

20. Dussupt V, Sankhala RS, Gromowski GD, Donofrio G, De La Barrera RA, Larocca RA, et al. Potent Zika and dengue cross-neutralizing antibodies induced by Zika vaccination in a dengue-experienced donor. Nat Med (2020) 26(2):228-35. doi: 10.1038/s41591-019-0746-2

21. Wang Q, Yang H, Liu X, Dai L, Ma T, Qi J, et al. Molecular determinants of human neutralizing antibodies isolated from a patient infected with Zika virus. Sci Trans Med (2016) 8(369):369ra179. doi: 10.1126/scitranslmed. aai8336

22. de Alwis R, Smith SA, Olivarez NP, Messer WB, Huynh JP, Wahala WM, et al. Identification of human neutralizing antibodies that bind to complex epitopes on dengue virions. Proc Natl Acad Sci United States America (2012) 109 (19):7439-44. doi: 10.1073/pnas.1200566109

23. Fibriansah G, Tan JL, Smith SA, de Alwis AR, Ng TS, Kostyuchenko VA, et al. A potent anti-dengue human antibody preferentially recognizes the conformation of $\mathrm{E}$ protein monomers assembled on the virus surface. EMBO Mol Med (2014) 6(3):358-71. doi: 10.1002/emmm.201303404

24. Smith SA, de Alwis AR, Kose N, Harris E, Ibarra KD, Kahle KM, et al. The potent and broadly neutralizing human dengue virus-specific monoclonal antibody 1C19 reveals a unique cross-reactive epitope on the bc loop of domain II of the envelope protein. MBio (2013) 4(6):e00873-13. doi: 10.1128/ mBio.00873-13

25. Barba-Spaeth G, Dejnirattisai W, Rouvinski A, Vaney MC, Medits I, Sharma A, et al. Structural basis of potent Zika-dengue virus antibody crossneutralization. Nature (2016) 536(7614):48-53. doi: 10.1038/nature18938

26. Fernandez E, Dejnirattisai W, Cao B, Scheaffer SM, Supasa P, Wongwiwat W, et al. Human antibodies to the dengue virus E-dimer epitope have therapeutic activity against Zika virus infection. Nat Immunol (2017) 18(11):1261-9. doi: 10.1038/ ni.3849 
27. Dejnirattisai W, Wongwiwat W, Supasa S, Zhang X, Dai X, Rouvinski A, et al. A new class of highly potent, broadly neutralizing antibodies isolated from viremic patients infected with dengue virus. Nat Immunol (2015) 16(2):170-7. doi: 10.1038/ni.3058

28. Abbink P, Larocca RA, Dejnirattisai W, Peterson R, Nkolola JP, Borducchi $\mathrm{EN}$, et al. Therapeutic and protective efficacy of a dengue antibody against Zika infection in rhesus monkeys. Nat Med (2018) 24(6):721-3. doi: 10.1038/ s41591-018-0056-0

29. Zhang S, Kostyuchenko VA, Ng TS, Lim XN, Ooi JS, Lambert S, et al. Neutralization mechanism of a highly potent antibody against Zika virus. Nat Commun (2016) 7:13679. doi: 10.1038/ncomms13679

30. Swanstrom JA, Plante JA, Plante KS, Young EF, McGowan E, Gallichotte EN, et al. Dengue Virus Envelope Dimer Epitope Monoclonal Antibodies Isolated from Dengue Patients Are Protective against Zika Virus. MBio (2016) 7(4): e01123-16. doi: 10.1128/mBio.01123-16

31. Fibriansah G, Ibarra KD, Ng TS, Smith SA, Tan JL, Lim XN, et al. Cryo-EM structure of an antibody that neutralizes dengue virus type 2 by locking $\mathrm{E}$ protein dimers. Science (2015) 349(6243):88-91. doi: 10.1126/science.aaa8651

32. Zhao H, Fernandez E, Dowd KA, Speer SD, Platt DJ, Gorman MJ, et al. Structural Basis of Zika Virus-Specific Antibody Protection. Cell (2016) 166 (4):1016-27. doi: 10.1016/j.cell.2016.07.020

33. Magnani DM, Rogers TF, Beutler N, Ricciardi MJ, Bailey VK, Gonzalez-Nieto L, et al. Neutralizing human monoclonal antibodies prevent Zika virus infection in macaques. Sci Transl Med (2017) 9(eaan8184):1-7. doi: 10.1126/scitranslmed. aan8184

34. Robbiani DF, Bozzacco L, Keeffe JR, Khouri R, Olsen PC, Gazumyan A, et al. Recurrent Potent Human Neutralizing Antibodies to Zika Virus in Brazil and Mexico. Cell (2017) 169(4):597-609 e11. doi: 10.1016/j.cell.2017.04.024

35. Niu X, Zhao L, Qu L, Yao Z, Zhang F, Yan Q, et al. Convalescent patientderived monoclonal antibodies targeting different epitopes of E protein confer protection against Zika virus in a neonatal mouse model. Emerg Microbes Infect (2019) 8(1):749-59. doi: 10.1080/22221751.2019.1614885

36. Zhao H, Xu L, Bombardi R, Nargi R, Deng Z, Errico JM, et al. Mechanism of differential Zika and dengue virus neutralization by a public antibody lineage targeting the DIII lateral ridge. J Exp Med (2020) 217(2):e20191792. doi: $10.1084 /$ jem.20191792

37. Keeffe JR, Van Rompay KKA, Olsen PC, Wang Q, Gazumyan A, Azzopardi SA, et al. A Combination of Two Human Monoclonal Antibodies Prevents Zika Virus Escape Mutations in Non-human Primates. Cell Rep (2018) 25 (6):1385-94 e7. doi: 10.1016/j.celrep.2018.10.031

38. Shrestha B, Brien JD, Sukupolvi-Petty S, Austin SK, Edeling MA, Kim T, et al. The development of therapeutic antibodies that neutralize homologous and heterologous genotypes of dengue virus type 1. PloS Pathog (2010) 6(4): e1000823. doi: 10.1371/journal.ppat.1000823

39. Gentry MK, Henchal EA, McCown JM, Brandt WE, Dalrymple JM. Identification of distinct antigenic determinants on dengue-2 virus using monoclonal antibodies. Am J Trop Med Hyg (1982) 31(3 Pt 1):548-55. doi: 10.4269/ajtmh.1982.31.548

40. Renner M, Flanagan A, Dejnirattisai W, Puttikhunt C, Kasinrerk W, Supasa P, et al. Characterization of a potent and highly unusual minimally enhancing antibody directed against dengue virus. Nat Immunol (2018) 19(11):1248-56. doi: 10.1038/s41590-018-0227-7

41. Stettler K, Beltramello M, Espinosa DA, Graham V, Cassotta A, Bianchi S, et al. Specificity, cross-reactivity, and function of antibodies elicited by Zika virus infection. Science (2016) 353(6301):823-6. doi: 10.1126/science.aaf8505

42. Wang J, Bardelli M, Espinosa DA, Pedotti M, Ng TS, Bianchi S, et al. A Human Bi-specific Antibody against Zika Virus with High Therapeutic Potential. Cell (2017) 171(1):229-41 e15. doi: 10.1016/j.cell.2017.09.002

43. Cockburn JJ, Navarro Sanchez ME, Goncalvez AP, Zaitseva E, Stura EA, Kikuti CM, et al. Structural insights into the neutralization mechanism of a higher primate antibody against dengue virus. EMBO J (2012) 31(3):767-79. doi: 10.1038/emboj.2011.439

44. Men R, Yamashiro T, Goncalvez AP, Wernly C, Schofield DJ, Emerson SU, et al. Identification of chimpanzee Fab fragments by repertoire cloning and production of a full-length humanized immunoglobulin G1 antibody that is highly efficient for neutralization of dengue type 4 virus. J Virol (2004) 78 (9):4665-74. doi: 10.1128/jvi.78.9.4665-4674.2004
45. Sapparapu G, Fernandez E, Kose N, Bin C, Fox JM, Bombardi RG, et al. Neutralizing human antibodies prevent Zika virus replication and fetal disease in mice. Nature (2016) 540(7633):443-7. doi: 10.1038/nature20564

46. Hasan SS, Miller A, Sapparapu G, Fernandez E, Klose T, Long F, et al. A human antibody against Zika virus crosslinks the $\mathrm{E}$ protein to prevent infection. Nat Commun (2017) 8:14722. doi: 10.1038/ncomms14722

47. Fibriansah G, Tan JL, Smith SA, de Alwis R, Ng TS, Kostyuchenko VA, et al. A highly potent human antibody neutralizes dengue virus serotype 3 by binding across three surface proteins. Nat Commun (2015) 6:6341. doi: 10.1038/ ncomms7341

48. Pettersen EF, Goddard TD, Huang CC, Couch GS, Greenblatt DM, Meng EC, et al. UCSF Chimera-a visualization system for exploratory research and analysis. J Comput Chem (2004) 25(13):1605-12. doi: 10.1002/ jcc. 20084

49. Rey FA, Stiasny K, Vaney MC, Dellarole M, Heinz FX. The bright and the dark side of human antibody responses to flaviviruses: lessons for vaccine design. EMBO Rep (2018) 19(2):206-24. doi: 10.15252/embr.201745302

50. Pierson TC, Fremont DH, Kuhn RJ, Diamond MS. Structural insights into the mechanisms of antibody-mediated neutralization of flavivirus infection: implications for vaccine development. Cell Host Microbe (2008) 4(3):22938. doi: 10.1016/j.chom.2008.08.004

51. Kostyuchenko VA, Lim EX, Zhang S, Fibriansah G, Ng TS, Ooi JS, et al. Structure of the thermally stable Zika virus. Nature (2016) 533(7603):425-8. doi: 10.1038/nature17994

52. Sirohi D, Chen Z, Sun L, Klose T, Pierson TC, Rossmann MG, et al. The $3.8 \AA$ resolution cryo-EM structure of Zika virus. Science (2016) 352(6284):467-70. doi: $10.1126 /$ science.aaf5316

53. Collins MH, Tu HA, Gimblet-Ochieng C, Liou GA, Jadi RS, Metz SW, et al. Human antibody response to Zika targets type-specific quaternary structure epitopes. JCI Insight (2019) 4(8):e124588. doi: 10.1172/jci.insight.124588

54. Dejnirattisai W, Supasa P, Wongwiwat W, Rouvinski A, Barba-Spaeth G, Duangchinda $\mathrm{T}$, et al. Dengue virus sero-cross-reactivity drives antibodydependent enhancement of infection with zika virus. Nat Immunol (2016) 17 (9):1102-8. doi: 10.1038/ni.3515

55. Priyamvada L, Quicke KM, Hudson WH, Onlamoon N, Sewatanon J, Edupuganti S, et al. Human antibody responses after dengue virus infection are highly cross-reactive to Zika virus. Proc Natl Acad Sci USA (2016) 113 (28):7852-7. doi: 10.1073/pnas.1607931113

56. Gordon A, Gresh L, Ojeda S, Katzelnick LC, Sanchez N, Mercado JC, et al. Prior dengue virus infection and risk of Zika: A pediatric cohort in Nicaragua. PloS Med (2019) 16(1):e1002726. doi: 10.1371/journal.pmed.1002726

57. Rodriguez-Barraquer I, Costa F, Nascimento EJM, Nery NJ, Castanha PMS, Sacramento GA, et al. Impact of preexisting dengue immunity on Zika virus emergence in a dengue endemic region. Science (2019) 363(6427):607-10. doi: $10.1126 /$ science.aav6618

58. Brady OJ, Osgood-Zimmerman A, Kassebaum NJ, Ray SE, de Araujo VEM, da Nobrega AA, et al. The association between Zika virus infection and microcephaly in Brazil 2015-2017: An observational analysis of over 4 million births. PloS Med (2019) 16(3):e1002755. doi: 10.1371/ journal.pmed.1002755

59. Sievers SA, Scharf L, West APJr., Bjorkman PJ. Antibody engineering for increased potency, breadth and half-life. Curr Opin HIV AIDS (2015) 10 (3):151-9. doi: 10.1097/COH.0000000000000148

60. Lee CH, Kang TH, Godon O, Watanabe M, Delidakis G, Gillis CM, et al. An engineered human $\mathrm{Fc}$ domain that behaves like a $\mathrm{pH}$-toggle switch for ultralong circulation persistence. Nat Commun (2019) 10(1):5031. doi: 10.1038/ s41467-019-13108-2

61. Lee CH, Romain G, Yan W, Watanabe M, Charab W, Todorova B, et al. IgG $\mathrm{Fc}$ domains that bind $\mathrm{C} 1 \mathrm{q}$ but not effector Fcgamma receptors delineate the importance of complement-mediated effector functions. Nat Immunol (2017) (18):889-98 doi: 10.1038/ni.3770

62. Saunders KO. Conceptual Approaches to Modulating Antibody Effector Functions and Circulation Half-Life. Front Immunol (2019) 10:1296:1296. doi: 10.3389/fimmu.2019.01296

63. Bardina SV, Bunduc P, Tripathi S, Duehr J, Frere JJ, Brown JA, et al. Enhancement of Zika virus pathogenesis by preexisting antiflavivirus immunity. Science (2017) 356:175-80. doi: 10.1126/science.aal4365 
64. Katzelnick LC, Narvaez C, Arguello S, Lopez Mercado B, Collado D, Ampie O, et al. Zika virus infection enhances future risk of severe dengue disease. Science (2020) 369(6507):1123-8. doi: 10.1126/science.abb6143

65. Lund J, Winter G, Jones PT, Pound JD, Tanaka T, Walker MR, et al. Fc gamma RI and Fc gamma RII interact with distinct but overlapping sites on human IgG. J Immunol (1991) 147(8):2657-62.

66. Wines BD, Powell MS, Parren PW, Barnes N, Hogarth PM. The IgG Fc contains distinct $\mathrm{Fc}$ receptor $(\mathrm{FcR})$ binding sites: the leukocyte receptors $\mathrm{Fc}$ gamma RI and Fc gamma RIIa bind to a region in the Fc distinct from that recognized by neonatal FcR and protein A. J Immunol (2000) 164(10):5313-8. doi: 10.4049 /jimmunol.164.10.5313

67. Hezareh M, Hessell AJ, Jensen RC, van de Winkel JG, Parren PW. Effector function activities of a panel of mutants of a broadly neutralizing antibody against human immunodeficiency virus type 1. J Virol (2001) 75(24):12161-8. doi: 10.1128/JVI.75.24.12161-12168.2001

68. Borrok MJ, Mody N, Lu X, Kuhn ML, Wu H, Dall'Acqua WF, et al. An "FcSilenced" IgG1 Format With Extended Half-Life Designed for Improved Stability. J Pharm Sci (2017) 106(4):1008-17. doi: 10.1016/j.xphs.2016.12.023

69. Rouvinski A, Dejnirattisai W, Guardado-Calvo P, Vaney MC, Sharma A, Duquerroy S, et al. Covalently linked dengue virus envelope glycoprotein dimers reduce exposure of the immunodominant fusion loop epitope. Nat Commun (2017) 8:15411. doi: 10.1038/ncomms15411

70. Metz SW, Gallichotte EN, Brackbill A, Premkumar L, Miley MJ, Baric R, et al. In Vitro Assembly and Stabilization of Dengue and Zika Virus Envelope Protein Homo-Dimers. Sci Rep (2017) 7(1):4524. doi: 10.1038/s41598-01704767-6

71. Metz SW, Thomas A, Brackbill A, Forsberg J, Miley MJ, Lopez CA, et al. Oligomeric state of the ZIKV E protein defines protective immune responses. Nat Commun (2019) 10(1):4606. doi: 10.1038/s41467-019-12677-6

72. Yu L, Wang R, Gao F, Li M, Liu J, Wang J, et al. Delineating antibody recognition against Zika virus during natural infection. JCI Insight (2017) 2 (12):e93042. doi: 10.1172/jci.insight.93042

73. Oliphant T, Engle M, Nybakken GE, Doane C, Johnson S, Huang L, et al. Development of a humanized monoclonal antibody with therapeutic potential against West Nile virus. Nat Med (2005) 11(5):522-30. doi: $10.1038 / \mathrm{nm} 1240$

74. Gallichotte EN, Young EF, Baric TJ, Yount BL, Metz SW, Begley MC, et al. Role of Zika Virus Envelope Protein Domain III as a Target of Human Neutralizing Antibodies. MBio (2019) 10(5):e01485-19. doi: 10.1128/ mBio.01485-19

75. Nybakken GE, Oliphant T, Johnson S, Burke S, Diamond MS, Fremont DH. Structural basis of West Nile virus neutralization by a therapeutic antibody. Nature (2005) 437(7059):764-9. doi: 10.1038/nature03956

76. Lu X, Xiao H, Li S, Pang X, Song J, Liu S, et al. Double Lock of a Human Neutralizing and Protective Monoclonal Antibody Targeting the Yellow Fever Virus Envelope. Cell Rep (2019) 26(2):438-46 e5. doi: 10.1016/ j.celrep.2018.12.065

77. Setliff I, Shiakolas AR, Pilewski KA, Murji AA, Mapengo RE, Janowska K, et al. High-Throughput Mapping of B Cell Receptor Sequences to Antigen Specificity. Cell (2019) 179(7):1636-46 e15. doi: 10.1016/j.cell.2019.11.003

78. Rogers TF, Goodwin EC, Briney B, Sok D, Beutler N, Strubel A, et al. Zika virus activates de novo and cross-reactive memory $\mathrm{B}$ cell responses in dengue- experienced donors. Sci Immunol (2017) 2(eaan6809):eaan6809. doi: 10.1126/ sciimmunol.aan6809

79. Magnani DM, Silveira CGT, Rosen BC, Ricciardi MJ, Pedreno-Lopez N, Gutman MJ, et al. A human inferred germline antibody binds to an immunodominant epitope and neutralizes Zika virus. PloS Negl Trop Dis (2017) 11(6):e0005655. doi: 10.1371/journal.pntd.0005655

80. Modjarrad K, Lin L, George SL, Stephenson KE, Eckels KH, De La Barrera RA, et al. Preliminary aggregate safety and immunogenicity results from three trials of a purified inactivated Zika virus vaccine candidate: phase 1 , randomised, double-blind, placebo-controlled clinical trials. Lancet (2018) 391(10120):563-71. doi: 10.1016/s0140-6736(17)33106-9

81. Mukherjee S, Sirohi D, Dowd KA, Chen Z, Diamond MS, Kuhn RJ, et al. Enhancing dengue virus maturation using a stable furin over-expressing cell line. Virology (2016) 497:33-40. doi: 10.1016/j.virol.2016.06.022

82. Quintel BK, Thomas A, Poer DeRaad DE, Slifka MK, Amanna IJ. Advanced oxidation technology for the development of a next-generation inactivated West Nile virus vaccine. Vaccine (2019) 37(30):4214-21. doi: 10.1016/ j.vaccine.2018.12.020

83. Abbink P, Larocca RA, De La Barrera RA, Bricault CA, Moseley ET, Boyd M, et al. Protective efficacy of multiple vaccine platforms against Zika virus challenge in rhesus monkeys. Science (2016) 353(6304):1129-32 doi: 10.1126/ science.aah6157

84. Larocca RA, Abbink P, Peron JPS, Zanotto P, Iampietro MJ, Badamchi-Zadeh A, et al. Vaccine protection against Zika virus from Brazil. Nature (2016). doi: 10.1038/nature18952

85. Cox F, van der Fits L, Abbink P, Larocca RA, van Huizen E, Saeland E, et al. Adenoviral vector type 26 encoding Zika virus (ZIKV) M-Env antigen induces humoral and cellular immune responses and protects mice and nonhuman primates against ZIKV challenge. PloS One (2018) 13(8):e0202820. doi: 10.1371/journal.pone.0202820

86. Xu K, Song Y, Dai L, Zhang Y, Lu X, Xie Y, et al. Recombinant Chimpanzee Adenovirus Vaccine AdC7-M/E Protects against Zika Virus Infection and Testis Damage. J Virol (2018) 92(6):e01722-17. doi: 10.1128/JVI.01722-17

87. Hassan AO, Dmitriev IP, Kashentseva EA, Zhao H, Brough DE, Fremont DH, et al. A Gorilla Adenovirus-Based Vaccine against Zika Virus Induces Durable Immunity and Confers Protection in Pregnancy. Cell Rep (2019) 28(10):263446 e4. doi: 10.1016/j.celrep.2019.08.005

88. Larocca RA, Mendes EA, Abbink P, Peterson RL, Martinot AJ, Iampietro MJ, et al. Adenovirus Vector-Based Vaccines Confer Maternal-Fetal Protection against Zika Virus Challenge in Pregnant IFN-alphabetaR(-/-) Mice. Cell Host Microbe (2019) 26(5):591-600 e4. doi: 10.1016/j.chom.2019.10.001

Conflict of Interest: The authors declare that the research was conducted in the absence of any commercial or financial relationships that could be construed as a potential conflict of interest.

Copyright (c) 2021 Dussupt, Modjarrad and Krebs. This is an open-access article distributed under the terms of the Creative Commons Attribution License (CC BY). The use, distribution or reproduction in other forums is permitted, provided the original author(s) and the copyright owner(s) are credited and that the original publication in this journal is cited, in accordance with accepted academic practice. No use, distribution or reproduction is permitted which does not comply with these terms. 